\title{
Advanced Yield Trial of Early Seeding, Higher Yield and Low Temperature Tolerant Breeding Lines of White Jute
}

\author{
Arju Miah ${ }^{1 *}$, Nihar Ranjan Saha², Amit Kumar Basunia ${ }^{3}$, AKM \\ Shahadat Hossain ${ }^{1}$ and Md Younus Ali $^{4}$ \\ ${ }^{1}$ Genetic Resources and Seed Division, Bangladesh Jute Research Institute, Bangladesh \\ ${ }^{2}$ Department of Biotechnology, Bangladesh Agricultural University, Mymensingh, \\ Bangladesh \\ ${ }^{3}$ Department of Horticulture, Bangladesh Agricultural University, Mymensingh, \\ Bangladesh \\ ${ }^{4}$ Fibre Quality Improvement Division, Bangladesh Jute Research Institute, Manik Mia \\ Avenue, Dhaka, Bangladesh \\ *Corresponding Author: Arju Miah, Genetic Resources and Seed Division, Bangladesh Jute \\ Research Institute, Manik Mia Avenue, Dhaka, Bangladesh.
}

DOI: 10.31080/ASAG.2020.04.0869

\begin{abstract}
The experiment was carried out at four regional stations (Rangpur, Chandina, Faridpur and Kishoreganj) and JAES, Manikganj to develop breeding lines with better performance in respect of seeding time and growth. Significant differences were observed among the treatments for plant population, plant height, base diameter and fibre weight at Manikganj, plant height and fibre weight at Rangpur and Chandina station. Pooled mean over stations revealed that the tested strains C-2234 (4.37 t/ha), C-2236 (4.12t/ha) and C-2281 (3.87 t/ha)out yielded both the check varieties BJRI Deshi Pat-5 (3.68 t/ha) and CC-45 (3.57 t/ha) in terms of fiber.
\end{abstract}

Keywords: Breeding Lines; Stress; Yield; Corchorus; White Jute

\section{Introduction}

Jute (Corchorus sp) is a natural long, soft, shiny vegetable fibre that can be spun into coarse, strong threads. It is produced from plants in the genus Corchorus, belonging to the family Tliaceae. Jute is considered as the main cash crop of Bangladesh. It's influence on ecology and economy is so intimate that it's effects are significantly related to the agro-ecology and the socioeconomic life of the people [1]. The suitable climate for growing jute (warm and wet climate) is the monsoon season. Temperatures ranging 20 to $40^{\circ} \mathrm{C}$ and a relative humidity of $70-80 \%$ are favorable for successful cultivation. Jute requires a weekly rainfall of $5-8 \mathrm{~cm}$ with an extra amount during the sowing period. Due to its good spinning quality, it is a good textile fibre. It helps to make best quality industrial yarn, fabric, net and sacks. It is one of the most versatile natural fibres that has been used in raw materials for packaging, textiles, non-textile, construction and agricultural sectors. Bulking of yarn results in a reduced breaking tenacity and an increased breaking extensibility when blended as a ternary blend [2].
Received: June 21, 2020

Published: June 30, 2020

(C) All rights are reserved by Arju Miah., et al. 
to maintain the uniformity of stand for better growth and development of plant. Hashim., et al. [5] reported that four plant densities (348, 261, 323 and 174 thousand acre $\left.^{-1}\right)$ were arranged in different planting patterns of $45,60,67.5 \mathrm{~cm} 90 \mathrm{sq} \mathrm{cm}$ plant $^{-1}$. Although there were no significant differences in yield between the treatments, higher densities of population produced higher yield. Among the sowing patterns $15 \mathrm{~cm} \times 7.5 \mathrm{~cm}$ had the highest yield followed by $22.5 \mathrm{~cm} \mathrm{x} 5 \mathrm{~cm}$ and $10 \mathrm{~cm} \mathrm{x} 11.25 \mathrm{~cm}$. However, 22.50 $\mathrm{cm}$ row width displayed better performance compared to other row widths. Cultural practices are important management factors that affect the yield of a crop.

The hot and humid climate coupled with intermittent rainfall during the jute-growing season, however, encourages weed growth resulting in severe crop-weed competition [6]; yield losses may be up to 75 to $80 \%$ [7]. Weeding is one of the most important cultural practices for the crop plants to take nutrients, moistures, light, space and sometimes controlling many diseases, organisms and insect pest [8]. An effective weed management practice is necessary for higher crop production and better economic return [9]. But, most effective and economic cultural practices for weed control in jute crop are not clearly known to our farmers. In Bangladesh, weeds are generally controlled by raking and niri (hand weeding) and weeding and thinning operations involve about $50 \%$ or more of the lobour cost [10]. Grasses constitute the dominant weed flora in jute fields and its management using pre-emergence herbicides is possible [11] provided the farmers get sufficient time for land preparation and herbicide application before sowing.

Development of short day and low temperature tolerant varieties having better yield of fibre and seed, grown in medium high and low land area is a prerequisite for intensive cultivation of white jute. Mean performance over stations revealed that the tested strains tested strains C-2234 (4.37 t/ha), C-2236 (4.12 t/ha) and C-2281 (3.87 t/ha) out yielded both the check varieties BJRI Deshi Pat-5 (3.68 t/ha) and CC-45 (3.57 t/ha) in terms of fiber in 2014. So, the trial will be carried out again at different locations by sowing them on $15^{\text {th }}$ March 2015 for evaluation of their yield and adaptability. Objectives of this study was to develop breeding lines with better performance in respect of seeding time and growth.

\section{Methodology}

The experiment was carried out at four regional stations (Rangpur, Chandina, Faridpur and Kishoreganj) and JAES, Manikganj. Three breeding lines viz. C-2234, C-2236, C-2281 along with two check varieties BJRI Deshi Pat-5 and CC-45 were grown. Seeds were sown on $15^{\text {th }}$ March 2014 . This experiment was laid out in a randomized complete block design with 3 replications having unit plot size of $4.5 \mathrm{~m} \times 3.0 \mathrm{~m}=13.5$ sq. $\mathrm{m}$. At the age of 120 days, the plants were harvested and data were recorded on plant population, plant height, base diameter, green weight with leaves, green weight without leaves, fibre weight and stick weight. Proper intercultural operations and standard agronomic practices were followed for uniform growth. The significance of differences between the means of the treatments was evaluated by one way analysis of variance followed by Duncan's Multiple Range Test at the significance level of $5 \%$ and least significance difference (LSD) test at $5 \%$ and $1 \%$ level of probability [12]. The statistical software Excel and MSTATC computer package program developed by Russel [13] were used for these analyses.

\section{Results}

Analysis of variance revealed significant differences among the treatments for plant population, plant height, base diameter and fibre weight at Manikganj, plant height and fibre weight at Rangpur and Chandina station (Table 1).

Plant population (m/ha): Plant population were significantly different in different lines in different locations. It ranged from (0.541 - $0.214 \mathrm{~m} / \mathrm{ha}$ ). Highest plant population $(0.367 \mathrm{~m} / \mathrm{ha}$ ) was observed from Manikganj in C-2236 line. Lowest plant population (0.214 m/ha) was observed from Rangpur in BJRI Deshi Pat-5.

Plant height (m): Plant height was highest (3.85m) in C-2281 line at Chindina, lowest $(2.53 \mathrm{~m})$ in C-2236 line at Kishoreganj which were statistically different from other lines of different locations. Average plant height was $3.36 \mathrm{~m}$.

Base diameter (mm): Base diameters were significantly different in different lines in different locations. It was ranged from 25.69 to $17.36 \mathrm{~mm}$. Highest base diameters (25.69 $\mathrm{mm}$ ) was observed from Rangpur in C-2234 line while lowest base diameters $(17.36 \mathrm{~mm})$ was observed from Rangpur in BJRI Deshi Pat-5.

Green weight with leaves (t/ha): It was ranged from 97.33 21.13 t/ha. Green weight with leaves was highest (97.33 t/ha) in CC-45 line at Rangpur while lowest (21.13 t/ha) in C-2234 line at Kishoreganj which were statistically different from other lines of different locations.

Green weight without leaves (t/ha): Green weight without leaves were significantly different in different lines in different locations. It was ranged from 73.47 - $15.36 \mathrm{t} / \mathrm{ha}$. Highest Green weight without leaves (73.47 t/ha) was observed from Chandina in C-2234 


\begin{tabular}{|c|c|c|c|c|c|c|c|}
\hline Stations & Varieties/lines & $\begin{array}{c}\text { Plant } \\
\text { population } \\
(\mathrm{m} / \mathrm{ha})\end{array}$ & $\begin{array}{l}\text { Plant } \\
\text { height } \\
\text { (m) }\end{array}$ & $\begin{array}{c}\text { Base } \\
\text { diameter } \\
(\mathrm{mm})\end{array}$ & $\begin{array}{l}\text { Green weight } \\
\text { with leaves } \\
\text { (t/ha) }\end{array}$ & $\begin{array}{c}\text { Green weight } \\
\text { without leaves } \\
\text { (t/ha) }\end{array}$ & $\begin{array}{c}\text { Stick } \\
\text { weight } \\
\text { (t/ha) }\end{array}$ \\
\hline \multirow[t]{8}{*}{ Manikiganj } & C-2234 & 0.346 & 3.13 & 23.47 & 64.44 & 50.52 & 8.34 \\
\hline & $\mathrm{C}-2236$ & 0.367 & 3.32 & 22.52 & 58.58 & 44.513 & 8.56 \\
\hline & C-2281 & 0.365 & 3.45 & 20.58 & 52.63 & 41.51 & 8.73 \\
\hline & BJRI Deshi Pat-5 & 0.347 & 3.37 & 20.52 & 56.55 & 39.36 & 8.58 \\
\hline & CC-45 & 0.353 & 3.53 & 20.47 & 58.42 & 47.67 & 9.72 \\
\hline & LSD (5\%) & 0.016 & 0.303 & 0.24 & NS & NS & NS \\
\hline & LSD (1\%) & 0.021 & 0.363 & 0.233 & NS & NS & NS \\
\hline & CV\% & 13.31 & 5.36 & 9.31 & 14 & 19.23 & 12.43 \\
\hline \multirow{8}{*}{ Rangpur } & C-2234 & 0.224 & 3.62 & 18.47 & 87.53 & 73.13 & 16.21 \\
\hline & C-2236 & 0.242 & 3.71 & 20.62 & 86.45 & 72.35 & 15.26 \\
\hline & C-2281 & 0.215 & 3.37 & 17.68 & 85.64 & 71.42 & 14.78 \\
\hline & BJRI Deshi Pat-5 & 0.214 & 3.35 & 17.36 & 70.46 & 59.26 & 12.63 \\
\hline & $\mathrm{CC}-45$ & 0.241 & 3.42 & 17.51 & 97.33 & 66.35 & 14.59 \\
\hline & LSD (5\%) & NS & 0.285 & NS & NS & NS & NS \\
\hline & LSD (1\%) & NS & 0.372 & NS & NS & NS & NS \\
\hline & $\mathrm{CV} \%$ & 9.11 & 4.63 & 10.31 & 17.14 & 9.15 & 10.31 \\
\hline \multirow[t]{8}{*}{ Chandina } & C-2234 & 0.236 & 3.57 & 22.74 & 89.58 & 73.47 & 11.67 \\
\hline & C-2236 & 0.241 & 3.59 & 23.38 & 77.56 & 64.45 & 11.63 \\
\hline & C-2281 & 0.234 & 3.85 & 23.31 & 72.85 & 61.74 & 10.35 \\
\hline & BJRI Deshi Pat-5 & 0.237 & 3.63 & 21.37 & 82.48 & 70.36 & 11.89 \\
\hline & CC-45 & 0.256 & 3.95 & 22.63 & 67.64 & 56.36 & 9.86 \\
\hline & LSD (5\%) & NS & 0.263 & NS & NS & NS & NS \\
\hline & LSD (1\%) & NS & 0.357 & NS & NS & NS & NS \\
\hline & CV\% & 10.16 & 3.47 & 12.42 & 17.55 & 17.32 & 15.32 \\
\hline \multirow[t]{8}{*}{ Faridpur } & C-2234 & 0.437 & 3.53 & 18.37 & 88.42 & 70.38 & 10.56 \\
\hline & C-2236 & 0.512 & 3.42 & 18.63 & 87.72 & 67.75 & 11.45 \\
\hline & C-2281 & 0.541 & 3.31 & 18.41 & 84.32 & 72.24 & 11.47 \\
\hline & BJRI Deshi Pat-5 & 0.536 & 3.51 & 17.65 & 76.26 & 68.26 & 10.53 \\
\hline & CC-45 & 0.531 & 3.54 & 18.52 & 80.38 & 64.75 & 12.31 \\
\hline & LSD (5\%) & NS & 0.41 & NS & NS & NS & NS \\
\hline & LSD (1\%) & NS & 0.31 & NS & NS & NS & NS \\
\hline & CV\% & 12.65 & 6.41 & 7.95 & 12.33 & 12.44 & 14.12 \\
\hline \multirow[t]{8}{*}{ Kishoreganj } & $\mathrm{C}-2234$ & 0.263 & 3.13 & 25.69 & 21.13 & 15.36 & 2.32 \\
\hline & C-2236 & 0.253 & 2.53 & 25.58 & 27.16 & 20.85 & 2.35 \\
\hline & C-2281 & 0.236 & 2.77 & 23.52 & 25.37 & 19.47 & 2.64 \\
\hline & BJRI Deshi Pat-5 & 0.263 & 2.68 & 22.74 & 26.58 & 19.43 & 2.42 \\
\hline & CC-45 & 0.287 & 2.73 & 20.46 & 24.64 & 19.67 & 2.61 \\
\hline & LSD (5\%) & NS & NS & NS & NS & NS & NS \\
\hline & LSD (1\%) & NS & NS & NS & NS & NS & NS \\
\hline & $\mathrm{CV} \%$ & 14.45 & 8.86 & 3.53 & 10.67 & 15.54 & 11.46 \\
\hline
\end{tabular}

Table 1: Mean fibre yield and yield contributing characters of three short day tolerant lines of white jute.

NS: Non-Significant. 
line, while lowest (15.36 t/ha) in C-2234 line at Kishoreganj. Average green weight without leaves was $53.22 \mathrm{t} / \mathrm{ha}$.

Stick weight (t/ha): Stick weight was ranged from 16.21 - $2.32 \mathrm{t} /$ ha. The highest (16.21 t/ha) in C-2234 line at Rangpur, while lowest (2.32 t/ha) in C-2234 line at Kishoreganj which were statistically different from other lines of different locations.

Fiber weight ( $t / h a)$ : Fiber weight were significantly different in different lines in different locations (Figure 1). Highest Fiber weight (5.76 t/ha) was observed from Rangpur in C-2234 line while lowest (0.84 t/ha) in C-2234 line at Kishoreganj. Average fiber weight was $3.92 \mathrm{t} / \mathrm{ha}$.

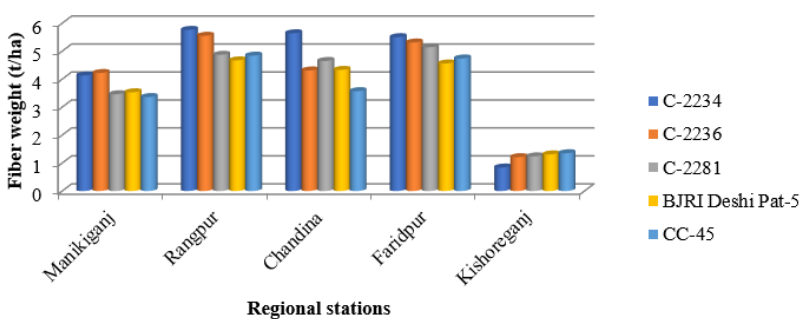

Figure 1: Fibre weight ( $\mathrm{t} / \mathrm{ha}$ ) of different lines of white jute in different regional station.
Pooled mean over stations (Table 2) revealed that the tested strains C-2234 (4.14 t/ha) out yielded both the check varieties BJRI Deshi Pat-5 (3.50 t/ha) and CC-45 (3.50 t/ha).

\section{Discussion}

Plant population were significantly different in different lines in different locations. Highest plant population $(0.367 \mathrm{~m} / \mathrm{ha})$ was observed from Manikganj in C-2236 line. Plant height was highest (3.85m) in C-2281 line at Chindina which was statistically different from other lines of different locations. In general, plant height is the most efficient morphological character which is directly related to greater fibre yield of Jute or Kenaf as well as the tallest plant maximizing the fibre yield of Jute or Kenaf. Similar findings were also obtained by Pervin., et al. [14] who observed that the analysis of variance significant differences among the genotypes for plant height.

Base diameters were significantly different in different lines in different locations. Highest base diameters (25.69 mm) was observed from Rangpur in C-2234 line. Significant varietals performance on base diameter were also obtained in jute [14-17]. Green weight with leaves was highest (97.33 t/ha) in CC-45 line at Rangpur which was statistically different from other lines of different locations. Green weight without leaves were significantly different in

\begin{tabular}{|c|c|c|c|c|c|c|c|c|c|}
\hline $\begin{array}{l}\text { Varieties/ } \\
\text { strains }\end{array}$ & Parentage & $\begin{array}{c}\text { Pedigree } \\
\text { number }\end{array}$ & $\begin{array}{c}\text { Plant } \\
\text { population } \\
\text { (m/ha) }\end{array}$ & $\begin{array}{l}\text { Plant } \\
\text { height } \\
\text { (m) }\end{array}$ & $\begin{array}{c}\text { Base di- } \\
\text { ameter } \\
(\mathrm{mm})\end{array}$ & $\begin{array}{c}\text { Green wt. } \\
\text { with leaves } \\
\text { (t/ha) }\end{array}$ & $\begin{array}{c}\text { Green wt. } \\
\text { without } \\
\text { leaves (t/ha) }\end{array}$ & $\begin{array}{c}\text { Fibre } \\
\text { weight } \\
\text { (t/ha) }\end{array}$ & $\begin{array}{c}\text { Stick } \\
\text { weight } \\
\text { (t/ha) }\end{array}$ \\
\hline C-2234 & $\begin{array}{c}\text { JRC-212 x } \\
\text { BZ-2 }\end{array}$ & $\begin{array}{c}912-7- \\
2234\end{array}$ & 0.301 & 3.40 & 21.75 & 70.22 & 56.57 & 4.37 & 9.82 \\
\hline C-2236 & $\begin{array}{l}\text { JRC-212x } \\
\text { JutaRoxa }\end{array}$ & $\begin{array}{l}914-3- \\
2236\end{array}$ & 0.323 & 3.31 & 22.15 & 67.49 & 53.98 & 4.12 & 9.85 \\
\hline C-2281 & $\begin{array}{c}\text { Hybrid C x } \\
\text { BZ-1-3 }\end{array}$ & $\begin{array}{c}9113-9- \\
2281\end{array}$ & 0.318 & 3.35 & 20.70 & 64.16 & 53.28 & 3.87 & 9.59 \\
\hline $\begin{array}{l}\text { BJRI Deshi } \\
\text { Pat-5 }\end{array}$ & - & - & 0.319 & 3.31 & 19.93 & 62.47 & 51.33 & 3.68 & 9.21 \\
\hline CC-45 & & - & 0.334 & 3.43 & 19.92 & 65.68 & 50.96 & 3.57 & 9.82 \\
\hline
\end{tabular}

Table 2: Pooled mean of the advanced short day tolerance lines of white jute at different stations.

different lines in different locations. Highest Green weight without leaves (73.47 t/ha) was observed from Chandina in C-2234 line. Pervin and Haque [14], Islam [15] reported that the green weight data were statistically similar among the Jute varieties.

Stick weight was highest (16.21 t/ha) in C-2234 line at Rangpur which was statistically different from other lines of different loca- tions. Fiber weight were different in different lines in different locations (Figure 1) which are not statistically significant. Highest Fiber weight was observed from Rangpur in C-2234 line. These were also found due to its genetic makeup and higher regional adaptability with the climatic condition and soil properties of the experimental field of the present study. Significant varietals performance on fibre 
yield were also obtained by Sanjoy., et al. [18], Hassan., et al. [19], Mollah., et al. [20], Hossain., et al. [21] and Islam., et al [22].

\section{Conclusion}

The result revealed that the tested strains C-2234 (4.37 t/ha), C-2236 (4.12 t/ha) and C-2281 (3.87 t/ha) out yielded both the check varieties BJRI Deshi Pat-5 (3.68 t/ha) and CC-45 (3.57 t/ha) in terms of fiber. This study should be continued for few year for further evaluation their yield and adaptability.

\section{Bibliography}

1. Masum SM., et al. "Effect of Abiotic Factors on Quality of Jute Seed". Bangladesh Research Publications Journal 4.1 (2010): 47-52.

2. Basu G., et al. "Properties of Jute Based Ternary Blended Bulked Yarns. Man-Made Textiles in India”. Indian Journal of Agricultural Science 48 (2005): 350-353.

3. Zakaria A and Sayed AN. "Jute microbiological and Biochemical Research". Plant Tissue Culture for Biotechnology 18.2 (2008): 197-220.

4. BBS (Bangladesh Bureau of Statistics). Statistical year Book of Bangladesh. Bangladesh Bureau of Statistics, Statistics Division, Ministry of Planning, Govt. of the people's Republic of Bangladesh (2011).

5. Hashim SA., et al. "Determination of optimum plant density for higher yield of C. capsularis L". Abstract of Researches, Agricultural research on jute, Bangladesh Jute Research Institute (1981): 253.

6. Saraswat VN. "Weed management in jute and jute based cropping system. Jute and Allied Fibres Agriculture and Processing. Palit, P., Pathak, S. and Singh, D.P. (editions.), Central Research Institute for Jute and Allied Fibres, Barrackpore (1999): 193-200.

7. Sahoo KM and Saraswat R. "Magnitude of losses in the yields of major crops due to weed competition in India". Pesti Info 14 (1988): 2-9.

8. Alam SM and Ali NM. "Weed management practice". Bangladesh Journal of Agricultural Research (2010): 174.

9. Gaffer SM., et al. "Effect of population density and harvesting time on yield and quality of white jute varieties". Annales Reports Bangladesh (1988): 130.
10. Alam SM. "Weed control method. Bangladesh". Jute fibers Resesah 10.1 (2003): 42-47.

11. Sarkar S., et al. "Weed management in jute by Trifluralin (48\% EC) in the early jute-weed competition phase". Journal of Crop and Weed 2 (2005): 30-33.

12. Gomez KA and Gomez AA. "Statistical procedures for agricultural research (2 $2^{\text {nd }}$ edition)" (1984): 188-240.

13. Russell DF. "MSTAT-C Package programme. Crop and Soil Science Department, Michigan State University, USA (1986).

14. Pervin N., et al. "Path Coefficient Analysis for fibre Yield Related Traits in Deshi Jute (Corchorus capsularis L.)". International Research Journal of Applied Life Science 1.3 (2012): 72-77.

15. Islam MM. "Variability and path coefficient analysis in jute (Corchoru solitorius L.) of indigenous origin. Digital Archive on Agricultural Theses and Journal”. N ${ }^{\circ}$ Catalog: SAU200701_112. Sher-E-Bangla Agricultural University, Sher-E-Bangla Nagar, Dhaka (2007).

16. Islam MR and Ahmad M. "Living in the coast: problems, opportunities and challenges". Program Dev. Office for Integrated Coastal Zone Management Plan Project; Water Resources Planning Organization. Dhaka, Bangladesh (2004).

17. Azad-ud-doula., et al. "Effect of water stresses on growth attributes in jute ii. plant based diameter". Pakistan Journal of Biological Science 4 (2001): 660-664.

18. Sanjoy Shil and Jiban Mitra. "JRC 9057 (Ishani): a newly developed white jute (Corchorus capsularis L.) variety for enhanced fibre yield and improved quality textile fibre". The Pharma Innovation Journal 7.7 (2018): 164-167.

19. Hassan KMM., et al. "Performance of some jute and allied fiber varieties in the southern part of Bangladesh". International Journal of Advanced Geosciences 6.1 (2018): 117-121.

20. Mollah MAF., et al. "Assessment of yield and quality of tossa jute (Corchorus olitorius l.) Seed as affected by variety and position OF BRANCH". Bangladesh Journal of Environmental Science 33 (2017): 63-67.

21. Hossain MS., et al. "Effect of sowing dates on fibre yield and yield attributes of white jute breeding line bjc-5003 at different locations of Bangladesh". International Journal of Sustainable Agricultural Technology 11.8 (2015): 1-6. 
22. Islam MM., et al. "Yield and quality of white jute (var. bjrideshi pat 8) seed as influenced by linexplant spacing in different growing areas of Bangladesh". American Research Journal of Agriculture 3.1 (2017): 1-6.

\section{Assets from publication with us}

- Prompt Acknowledgement after receiving the article

- Thorough Double blinded peer review

- Rapid Publication

- Issue of Publication Certificate

- High visibility of your Published work

Website: https://www.actascientific.com/

Submit Article: https://www.actascientific.com/submission.php Email us: editor@actascientific.com

Contact us: +919182824667 